\title{
Ecological patterns for vegetation cover formation in the mining waste dumps of the Lviv-Volyn coal basin
}

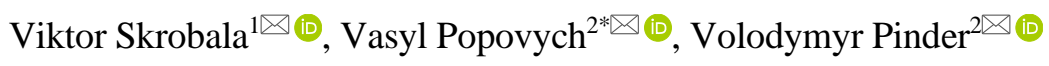 \\ ${ }^{1}$ Ukrainian National Forestry University, Lviv, 79057, Ukraine \\ ${ }^{2}$ Lviv State University of Life Safety, Lviv, 79007, Ukraine \\ *Corresponding author: e-mail popovich2007@ukr.net, tel.+380676733265
}

\begin{abstract}
Purpose. Determination of ecological patterns for vegetation cover formation in the mining waste dumps of the Lviv-Volyn coal basin based on the ecotopes floristic composition analysis of waste heaps reclaimed and non-reclaimed.

Methods. The phytoindication of ecological regimes is used based on the ecological parameters of herbaceous species of vegetation covering the mining waste dumps; data retrieval techniques (Data Mining methods); plant species multivariate ordination based on the main components analysis (Principle Component Analysis); statistical processing of ecotopes ecological parameters of the mining waste dumps.

Findings. A phytoindication assessment has been performed of the conditions in the places of growing 8 ecological-cenotic groups and 5 subgroups of plant species representing various ecotopes of reclaimed and non-reclaimed waste dumps of mines according to nine parameters: $\mathrm{Tm}$ - thermal regime, $\mathrm{Kn}$ - climate continentality, $\mathrm{Om}$ - ombroclimate, $\mathrm{Cr}-\mathrm{cryocli}$ mate, $H d$ - soil moisture, $T r$ - salt content, $R c$ - soil acidity, $N t$ - mineral nitrogen, $L c$ - luminosity-shadowing regime. It has been found that with decreasing parameters of climate humidity, shadowing in cenosis and soil moisture, the indexes of thermal regime, continentality, soil pH and salt content increase. It is recommended to present the typological scheme of the vegetation covering the mining waste dumps in the form of a quadrangle, in the centre of which meadow and synanthropic vegetation is located, and in the corners - boreal and psammophilous vegetation; nemoral-forest; hydrophilous; meadowsteppe and calcetrophilic.

Originality. It has been revealed that the vegetation covering the mining waste dumps of the Lviv-Volyn coal basin is characterized by an ecological-cenotic areal. It has been assessed on the basis of the species ordination on the axes of complex environmental gradients, and the center of this areal is occupied by meadow and synanthropic species, which demonstrate greatest sustainability under the conditions of mining waste dumps. The most vulnerable species are meadow-steppe, calciphilous, hydrophilous vegetation, the ecological-cenotic areal of which is characterized by the location on the periphery of the general vegetation areal of mining waste dumps.

Practical implications. The ecological parameters of flora species make it possible to determine their position in the ecological-cenotic areal of vegetation covering the mining waste dumps of the Lviv-Volyn coal basin, as well as to predict their sustainability and dynamics.
\end{abstract}

Keywords: mining engineering, mining waste dump, ecological safety, vegetation

\section{Introduction}

The Lviv-Volyn coal basin is located in the western part of Ukraine. Chervonohrad coal mining industrial region is the largest in the area. Since 1956, 12 coal mines and Chervonohradska central beneficiation plant have been operated in the region [1]. Significant ecological problems in Chervonohrad mining region are resulted from the negative environmental impact of solid industrial waste produced in the coal industry [2], [3]. The rocks stored in dumps (waste heaps) are characterized by a high content of heavy metals, low water-absorption capacity, low nutrient content[4]-[6]. Waste dumps contain a large number of autogenous sub- stances that can smolder for a long time, releasing into the atmosphere the carbon monoxide and dioxide, dioxide of both sulfur and hydrogen sulfide, as well as nitrogen oxide and dioxide [1].

After a large number of mines were closed, reclamation measures were conducted in separate dumps with the use of soil mixtures with a thickness of $40-50 \mathrm{~cm}$, as well as applying artificial afforestation. Given the ability of waste dumps to self-organized vegetation, studying the patterns for certain plant species propagation, as well as the formation of disturbed ecotopes vegetation cover is of great practical importance [1]. 
The applied research on improving the ecological restoration efficiency of coal mines by means of phytomelioration is presented in the work [7]. An experiment and field studies have been conducted to reveal the micromycetes influence on plant growth capacity. Such an approach has led to the development of environmentally-friendly technologies for soil restoration through phytoreclamation. The reclamation work is closely related to land use planning [8]. Dumps can retain their original state without levelling or with minimal levelling of their surface. Another possibility is the partial unloading of waste to a dump, and then levelling of its surface if necessery. The best way out is to completely clear up the dump and conduct reclamation of this land [9]. It has been experimentally proved [10], that the waste dumps phytomelioration is an effective means of reducing flow and erosion of soil and an essential component for ecosystem restoration in ecologically hazardous regions. It should be noted the positive role of soil algae in the higher plants development in waste dumps.

The study [11] substantiates, that a large number of soil algae in the dumps of copper mines increases due to a decrease in heavy metals content and an improvement of nutritious conditions. The soil algae growth creates the conditions for dispersion and growth of higher plants. Moss and vascular plants appearing in the dumps of copper mines keep down the soil algae development.

Along with this, it should be noted that there are various technologies for extracting minerals from waste dumps of coal mines [12]-[14], quarries [15], [16], and small mining enterprises [17]-[19], which makes possible to obtain additional energy sources in the process of mining operations. At the same time, some scientists note the influence of mining operations on the quality of minerals extraction [20], [22].

\section{Objects and methods of research}

The research area is located in the geobotanical district of Male Polissia. It is characterized by plane-earth surfaces, widespread sands and sod-podzolic sandy soils, pine and oak-pine forests, meadows, as well as significant degree of marshiness. The most widespread sod-podzolic sandy soils are characterized by low humus content (0.6-1.3\%), acidic reaction $(\mathrm{pH}=5.33-6.14)$ and a small volume of active nutrients [23]. The climate is Atlantic-continental, which is characterized by significant amount of rainfall $(620-750 \mathrm{~mm})$, mild winters with frequent thaws and unstable snow cover, as well as moderately warm summers without long-term droughts and dry winds.

The waste dumps of coal mines are constructed mainly of coarse fractions (over $50 \mathrm{~mm}$ ) of mined-out, partially burnt rock, which is by $70 \%$ composed of clay argillites. Dumps up to $60 \mathrm{~m}$ high and a base area of more than 10 ha often have a compound relief form [1].

The ecological patterns for plants propagation under the conditions of mining waste dumps in Chervonohrad coal mining industrial region are studied using data retrieval methods [24]. Data retrieval method is a process of analytical research into large amounts of information in order to identify certain patterns and dependences between variables (hidden knowledge) that can be applied to new data sets, as well as reliable prediction of processes and phenomena [24]. Unlike traditional statistical methods, data retrieval procedures are based on the "black box" principle and are more oriented towards the practical use of the obtained results [24]. The research consists of three main stages: studying the structure of species mutual arrangement in a many-dimensional space of ecological parameters features, mathematical structure modeling, and mathematical model testing.

The concept of our research is to mathematically model the structure of species arrangement in the hyperspace of features. Since it is visually impossible to recognize a structure in the many-dimensional space, the main attention is paid to multivariate ordination methods. The task of mathematical modelling is to replace a large numbers array (ecological parameters of species) with such scattering of points that would help to reveal its structure as a reflection of ecological patterns [3].

The basis for geobotanical data is information on the ecological conditions for the growth places of eighty-nine herbaceous species representing various ecotopes of reclaimed and non-reclaimed waste dumps, according to nine parameters: $\mathrm{Tm}$ - thermal regime, $\mathrm{Kn}$ - climate continentality, $\mathrm{Om}$ ombroclimate, $\mathrm{Cr}$ - cryoclimate, $\mathrm{Hd}$ - soil moisture, $\mathrm{Tr}$ - salt content, $R c$ - soil acidity, $N t-$ mineral nitrogen, $L c-$ luminosity regime - shadowing (I, J). In addition to own research, literature sources data were also used [1], [2], [25], [26].

Mathematical modeling is conducted by setting systematic relationships between the ecological parameters of the places of plant species growth [24]. Each species can be represented as a point in a many-dimensional space of features, the coordinates of which correspond to the ecological regimes parameters values. In this case, the species similarity according to the ecological parameters set can be determined based on the distances between the points. The essence of the further mathematical procedure is to identify the axes of maximum variation, determine their quantity, assess the value of each ecological parameter for variation based on the main components analysis [24]. The mathematical model verification is performed on the basis of a comparative assessment of the species position on the axes of maximum variation (multivariate ordination) with the results of geobotanical studies and data of literature sources [1][2][25][26].

Ecological and phytocenological analysis is one of the methods for understanding the patterns of formation, functioning and predictioning the vegetation cover dynamics. This analysis is based on the plant species classification according to the feature of identity to a particular type of plant communities [26]. Data on sustainable species combinations (ecological-cenotic groups of species), which are characterized by a similar attitude to environmental conditions and are met in single-type phytocenosis, are widely used in modern botanical studies [27]. When analysing the ecological-cenotic composition of the vegetation cover communities in the mining waste dumps of Chervonohrad coal mining industrial region, our research objective is to determine the arrangement of the ecological-cenotic groups of species on the ecological factors gradients.

\section{Results and discussion}

Based on own research and analysis of literature sources [1], [2], [25], [26], 8 ecological-cenotic groups and 5 subgroups of plant species have been identified in the vegetation cover of the mining waste dumps in Chervonohrad coal mining industrial region (Table 1). The largest number of species is characteristic of synanthropic, meadow, and nemoral-forest ecological-cenotic groups. 
Table 1. System of ecological-cenotic groups of vegetation cover species in the waste heaps of Chervonohrad coal mining industrial region

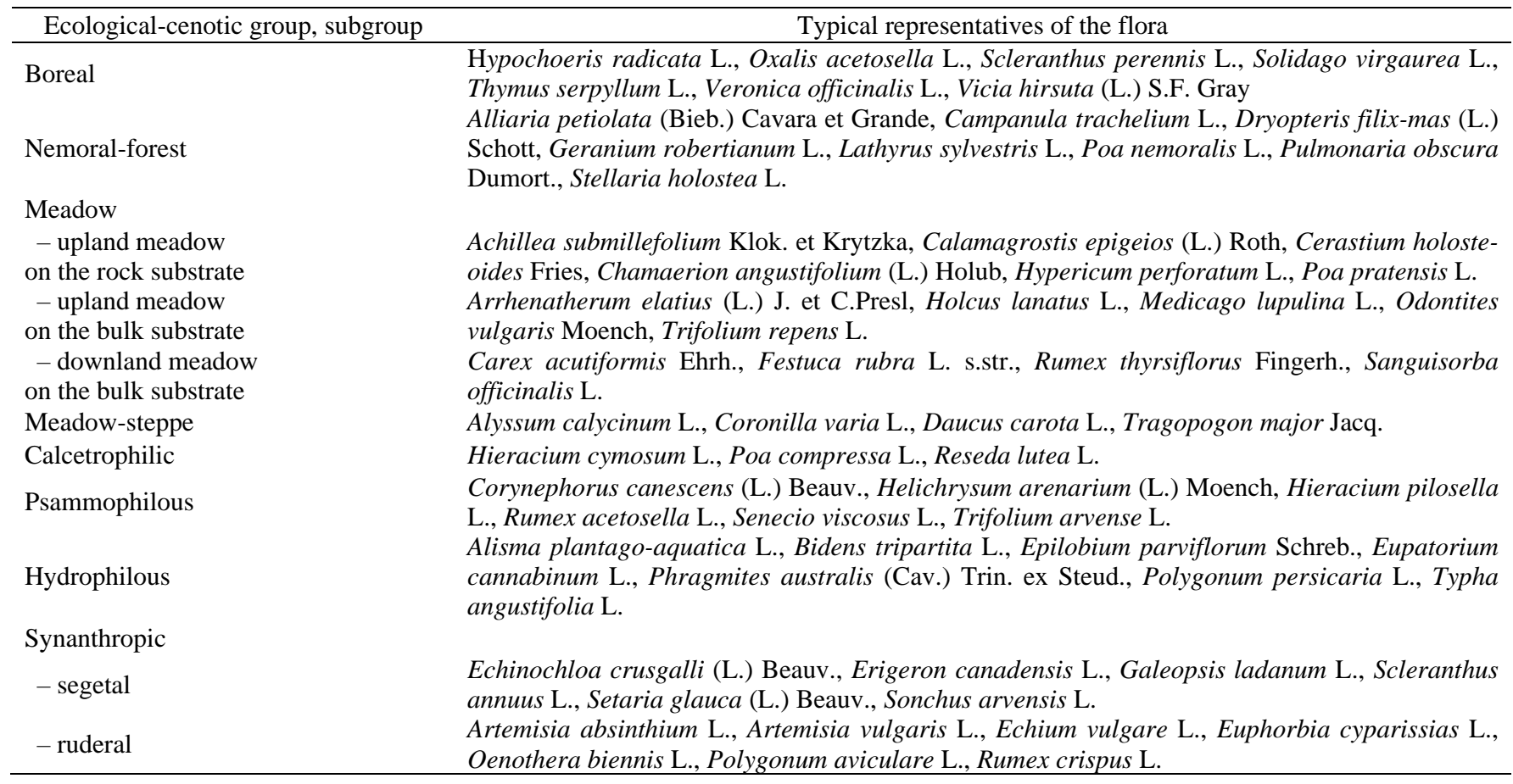

The climate regime peculiarities on the territory are determined by geographical latitude, altitude above sea-level, the geological substrate nature $(\mathrm{J})$. The waste dumps microclimate is often different from the microclimate of natural plant communities. The high steepness of the dumps surface is the reason of contrasts in solar radiation incoming to the slopes of different exposures. The rock dark colour and its low specific heat capacity cause the death of plants due to strong heating and rapid drying of the rock surface layers [1]. At the level of ecological-cenotic plant groups, the thermal regime of the mining waste dumps in Chervonohrad coal mining industrial region is characterized by a relatively narrow range of thermal regime parameters $(T m=8.17-9.38$ points $)$. This corresponds to the boreal-nemoral and nemoral types of thermal regime with radiation balance values of $40-45 \mathrm{kcal} /\left(\mathrm{cm}^{2} \cdot\right.$ year) [28], [29]. The maximum values of the thermal regime parameters are characteristic of the meadow-steppe and ruderal subgroups, and the minimum values - the upland meadow on the bulk substrate and psammophilous ecological-cenotic group (Table 2). There is a noticeable difference in the thermal regime for vegetation growth places of upland meadow on the rock substrate and bulk substrate. By applying the layers of bulk soil mixtures on the waste dump, it is possible to decrease their temperature compared to the rock substrate.

Table 2. Ecological parameters of the growth places in the mining waste dumps

\begin{tabular}{|c|c|c|c|c|c|c|c|c|c|}
\hline \multirow{2}{*}{$\begin{array}{l}\text { Ecological-cenotic group, } \\
\text { subgroup of plants }\end{array}$} & \multicolumn{9}{|c|}{ Average ecological parameters values of the growth places, points } \\
\hline & $T m$ & $K n$ & $O m$ & $\mathrm{Cr}$ & $H d$ & $\operatorname{Tr}$ & $R c$ & $N t$ & $L c$ \\
\hline Boreal & 8.44 & 7.69 & 8.19 & 8.56 & 10.56 & 5.50 & 5.31 & 4.31 & 3.69 \\
\hline Nemoral-forest & 8.55 & 7.77 & 7.95 & 8.59 & 12.59 & 6.68 & 7.68 & 6.68 & 5.05 \\
\hline Meadow & 8.40 & 8.82 & 7.62 & 7.42 & 11.55 & 7.75 & 7.45 & 5.63 & 2.85 \\
\hline - upland meadow on the rock substrate & 8.17 & 8.72 & 7.61 & 7.28 & 11.28 & 7.11 & 6.89 & 5.72 & 3.22 \\
\hline - upland meadow on the bulk substrate & 9.00 & 8.64 & 7.71 & 8.00 & 10.93 & 8.29 & 7.86 & 5.57 & 2.57 \\
\hline - downland meadow on the bulk substrate & 7.88 & 9.38 & 7.50 & 6.75 & 13.25 & 8.25 & 8.00 & 5.50 & 2.50 \\
\hline Meadow-steppe & 9.38 & 8.75 & 7.13 & 9.25 & 8.13 & 8.38 & 8.75 & 4.75 & 2.25 \\
\hline Calcetrophilic & 8.67 & 8.83 & 6.83 & 9.33 & 8.33 & 6.33 & 9.33 & 4.00 & 2.00 \\
\hline Psammophilous & 8.23 & 8.59 & 7.68 & 7.64 & 9.91 & 5.77 & 5.59 & 4.23 & 2.55 \\
\hline Hydrophilous & 8.93 & 8.68 & 7.86 & 7.96 & 15.46 & 7.89 & 7.04 & 7.21 & 3.07 \\
\hline Synanthropic & 8.79 & 8.62 & 7.68 & 8.21 & 10.35 & 7.62 & 6.76 & 6.32 & 2.50 \\
\hline - segetal & 9.31 & 8.56 & 7.69 & 8.75 & 10.50 & 7.56 & 7.00 & 6.31 & 2.44 \\
\hline - ruderal & 8.33 & 8.67 & 7.67 & 7.72 & 10.22 & 7.67 & 6.56 & 6.33 & 2.56 \\
\hline Mean & 8.62 & 8.49 & 7.72 & 8.10 & 11.51 & 7.14 & 6.97 & 5.78 & 3.10 \\
\hline Std. Dev. & 0.88 & 0.85 & 0.64 & 1.21 & 2.54 & 1.60 & 1.64 & 1.82 & 1.15 \\
\hline
\end{tabular}

The climate continentality is determined by the influence of large land areas on atmospheric and climate-forming processes. Continentality depends on the air annual amplitude and the deficit of relative humidity. Hemicontinental climate is typical for the studied area ( $K n=9$ points).

The minimum continentality values are characteristic of the places for growing boreal and nemoral-forest ecological- phytocenotic plant groups (Table 2). At the species level, the maximum continentality parameters are characteristic of the following species Hypericum perforatum, Echium vulgare, Coronilla varia, Potentilla norvegica, Helichrysum arenarium, Reseda lutea, as representatives of synanthropic, psammophilous, calcetrophilic and meadow-steppe ecologicalphytocenotic groups. 
The climate humidity index (ombroclimate) $\mathrm{Om}$ represents the difference in annual amount of precipitation and evaporation (maximum possible evaporation under given climatic conditions from the geological substrate with unlimited moisture reserves). Minimum humidity parameters are recorded for the growth places of meadow-steppe and calcetrophilic ecological-phytocenotic groups $(\mathrm{Om}=6.83-7.13$ points $)$ - subarid type of ombroregime (Table 2). In plant communities of other ecological-cenotic groups, the range of humidity parameters indicates an intermediate type between the subarid and subhumid types of ombroregime. The maximum values of the climate humidity parameters are characteristic of the growth places of boreal and nemoral-forest vegetation.

One of the important ecological factors is the climate frozen condition (cryoclimate) $\mathrm{Cr}$. Plant growth is stopped in autumn with a steady change to an average daily temperature less than $5^{\circ} \mathrm{C}$. Very often, the conditions of plants wintering are determined by possibilities of their growth in a particular ecotope. The maximum values of cryoclimate parameters are characteristic of the growth places of meadow-steppe and calcetrophilic ecological-cenotic groups $(\mathrm{Cr}=9.25-9.33$ points) - the regime of mild winters with the coldest month temperature of $-6 \ldots-2^{\circ} \mathrm{C}$. In plant communities of other ecological-cenotic groups, the range of cryoclimate parameters indicates an intermediate type between the regimes of moderate winters and mild winters. The minimum values of cryoclimate parameters are characteristic of the growth places of downland meadow ecological-cenotic subgroup $(C r=6.75$ points $)$ - the regime of moderate winters with the coldest month temperature of $-14 \ldots-10^{\circ} \mathrm{C}$. (Table 2 ).

The moisture supply regime in the mining waste dumps of Chervonohrad coal mining industrial region is characterized by the greatest variability in comparison with other ecological factors (Table 2). This is conditioned by the low waterretaining rock capacity, heterogeneous terrain conditions, the presence of reclaimed areas with bulk soil. Minimum soil moisture parameters $(H d=8.13-8.33$ points) are characteristic of the growth places of meadow-steppe and calcetrophilic vegetation in a fresh-steep type of moisture regime. The growth places of the hydrophilous ecological-cenotic group are characterized by maximum soil moisture parameters ( $H d=15.46$ points $)$ - damp forest-meadow and wet forest-meadow types of moisture regimes. The most optimal soil moisture supply conditions (fresh and moist types) are observed in reclaimed areas with nemoralforest vegetation ( $H d=12.59$ points).

The salt content in the soil significantly affects the conditions of soil formation and plants propagation. Due to the high content of heavy metals, salts, emission of harmful gases during substrate oxidation, the mining waste dumps are extremely toxic to plants. The process of edaphotope formation and plants dispersion on it lasts for decades and is characterized by the following time stages: oxidation, scouring, and plants overgrowth. Places of vegetation growth in mining waste dumps are characterized by a sufficiently wide range of salt regime parameters, as for a relatively small area ( $\operatorname{Tr}=5.50-8.38$ points). This corresponds to the gradient from nutrient-poor soils to fertile soils. Nutrient-poor soils ( $\operatorname{Tr}=5.50-5.77$ points) are characteristic of the growth places of boreal and psammophilous ecological-cenotic groups of vegetation. The maximum values of the salt regime parameters are characteristic of the ecotopes of meadow-steppe, downland meadow and upland meadow vegetation on the bulk substrate $(\mathrm{Tr}=8.25-8.38$ points). At the species level, indicators of weakly-salinized soils are: Sonchus arvensis, Alisma plantago-aquatica, Medicago falcata, Setaria glauca, Polygonum aviculare, Tragopogon dubius, Bidens tripartita, Calamagrostis epigeios, Festuca rubra.

The oxidation of the sulphur-containing pyrite mineral involving the thionic bacteria and with the sulphuric acid formation determines the high acidity of the mining waste dumps at the first stages of the edaphotope formation. At the species level, indicators of highly acidic soils are Rumex acetosella, Scleranthus annuus, Chamaenerion angustifolium, Juncus bufonius, Corynephorus canescens. Acidic soils ( $R c=5.31-5.59$ points $)$ are characteristic of the growth places of boreal and psammophilous ecological-cenotic groups of vegetation (Table 2). The neutral soils are characteristic of the ecotopes with calcetrophilic and meadow-steppe vegetation $(R c=8.75-9.33$ points).

Ecotopes of the mining waste dumps in Chervonohrad coal mining industrial region differ significantly in the nitrogen content in the soil (Table 2) - from very nitrogen-poor soil $(N t=4.00-4.23$ points $)$ in the ecotopes with calcetrophilic and psammophilous vegetation to sufficiently nitrogen-rich soils $(N t=6.79-7.21$ points $)$ in the ecotopes with hydrophilous and nemoral-forest vegetation. The indicators of low nitrogen content in the soil are the following species Thymus serpyllum, Helichrysum arenarium, Scleranthus perennis, Trifolium arvense, Corynephorus canescens, Hieracium pilosella. The presence in the herbaceous cover of species such as Alliaria petiolata, Galium aparine, Myosoton aquaticum, Solanum dulcamara, Campanula trachelium, Epilobium roseum, Eupatorium cannabinum indicates a high nitrogen content in the soil.

The ecological structure of the vegetation cover in the mining waste dumps of Chervonohrad coal mining industrial region is dominated by open and semi-open spaces $(L c=1-3$ points). The maximum values of the luminosity-shadowing parameter $L c$ are characteristic of nemoral-forest ecologicalcenotic group of vegetation: Poa nemoralis, Dryopteris filixmas, Moehringia trinervia and others.

An analysis of dependence between the ecological parameters of herbaceous species (Table 3 ) indicates the absence of a close link between the variables. Correlation coefficients are characterized by low values, and only for the temperature regime parameters of cryoregime, this index exceeds 0.5 .

In most cases, the relationship between the variables is of curvilinear nature (Fig. 1).

Table 3. Dependence between the ecological parameters of herbaceous species in the mining waste dumps and complex environmental gradients

\begin{tabular}{cccccccccc}
\hline & $\mathrm{Tm}$ & $\mathrm{Kn}$ & $\mathrm{Om}$ & $\mathrm{Cr}$ & $\mathrm{Hd}$ & $\mathrm{Tr}$ & $\mathrm{Rc}$ & $\mathrm{Nt}$ & $\mathrm{Lc}$ \\
\hline $\mathrm{Tm}$ & 1.00 & 0.02 & -0.24 & 0.60 & -0.09 & 0.22 & 0.23 & 0.15 & -0.09 \\
$\mathrm{Kn}$ & 0.02 & 1.00 & -0.45 & -0.46 & -0.07 & 0.23 & 0.08 & 0.02 & -0.35 \\
$\mathrm{Om}$ & -0.24 & -0.45 & 1.00 & -0.18 & 0.27 & -0.00 & -0.20 & 0.04 & 0.24 \\
$\mathrm{Cr}$ & 0.60 & -0.46 & -0.18 & 1.00 & -0.22 & -0.11 & 0.14 & -0.05 & 0.08 \\
$\mathrm{Hd}$ & -0.09 & -0.07 & 0.27 & -0.22 & 1.00 & 0.19 & -0.03 & 0.44 & 0.33 \\
$\mathrm{Tr}$ & 0.22 & 0.23 & -0.00 & -0.11 & 0.19 & 1.00 & 0.43 & 0.30 & -0.25 \\
$R c$ & 0.23 & 0.08 & -0.20 & 0.14 & -0.03 & 0.43 & 1.00 & 0.16 & -0.11 \\
$N t$ & 0.15 & 0.02 & 0.04 & -0.05 & 0.44 & 0.30 & 0.16 & 1.00 & 0.29 \\
$L c$ & -0.09 & -0.35 & 0.24 & 0.08 & 0.33 & -0.25 & -0.11 & 0.29 & 1.00 \\
\hline Factor 1 & 0.55 & 0.51 & -0.69 & 0.26 & -0.45 & 0.41 & 0.51 & -0.11 & -0.62 \\
\hline Factor 2 & 0.10 & 0.21 & 0.12 & -0.29 & 0.68 & 0.69 & 0.41 & 0.76 & 0.17 \\
\hline Factor 3 & -0.63 & 0.66 & -0.07 & -0.86 & -0.04 & 0.05 & -0.21 & -0.23 & -0.39 \\
\hline Factor 4 & 0.12 & 0.36 & -0.58 & 0.03 & 0.13 & -0.41 & -0.30 & 0.32 & 0.38 \\
\hline
\end{tabular}




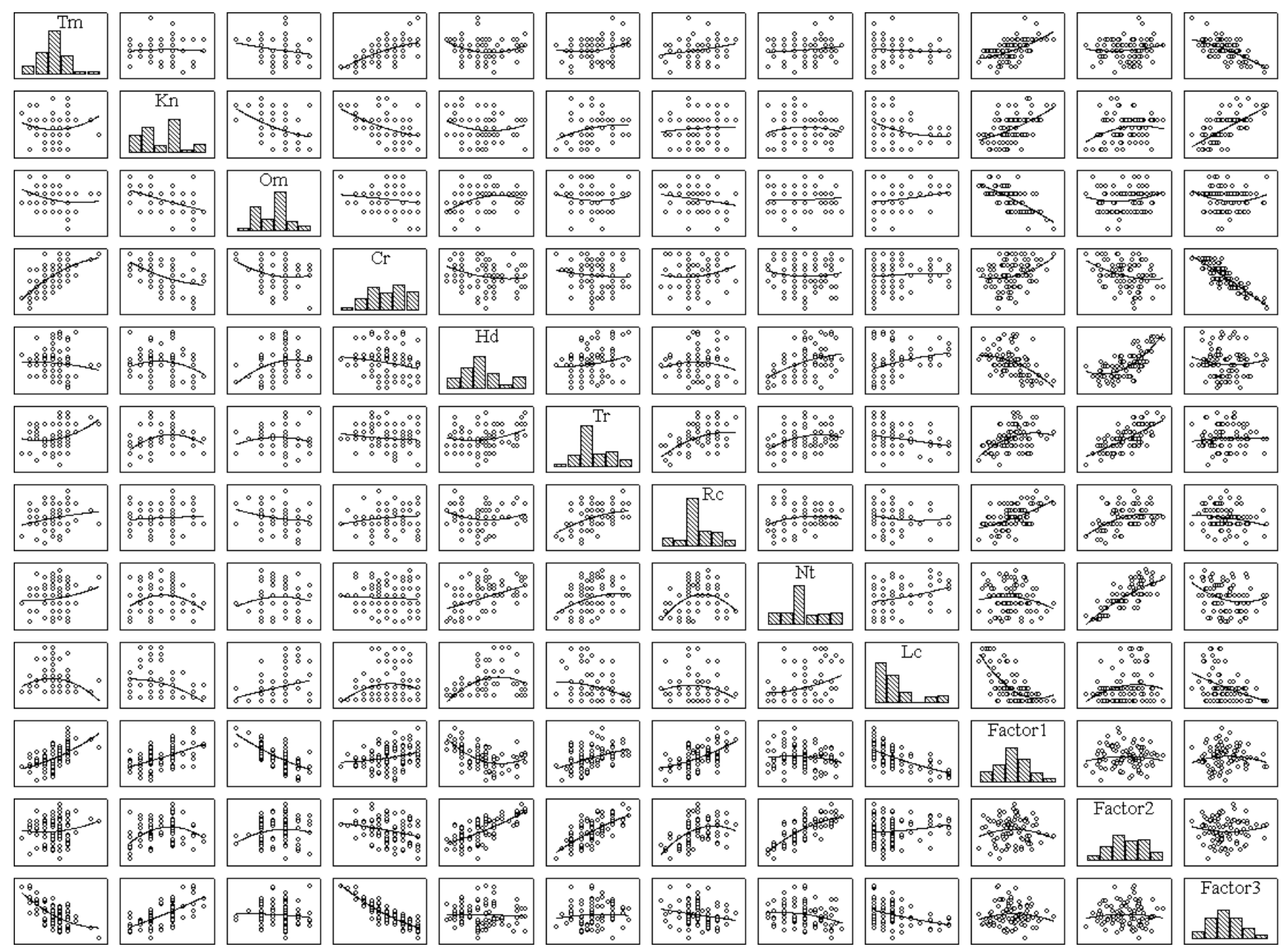

Figure 1. Dependence diagram between the ecological parameters of herbaceous cover species in the mining waste dumps and complex environmental gradients. Conventional signs: Tm-thermal regime; Kn-climate continentality; Om-ombroclimate; $\mathrm{Cr}$-cryoclimate; $\mathrm{Hd}$-soil moisture; $\mathrm{Tr}$-salt content; $\mathrm{Rc}$-soil acidity; $\mathrm{Nt-mineral} \mathrm{nitrogen;} \mathrm{Lc-luminosity-shadowing}$ regime; Factor - complex environmental gradients

Significant points deviations from the regression curve testify the absence of a well-ordered structure of the species arrangement in a many-dimensional space of ecological parameters features. As a result, two-dimensional dispersion diagrams have not allowed to reveal definite patterns, on the basis of which it would be possible to explain the peculiarities of species propagation in the mining waste dumps of Chervonohrad coal mining industrial region.

Since the ecological parameters of the herbaceous cover species in the mining waste dumps correlate to each other, it can be concluded that the observational data can be explained by a small number of new variables that are not directly measured, but can be obtained through a linear combination of outcoming data. This makes it possible to reduce the dimensionality of the observation space. Graphically, the calculation procedure is reduced to displacement of origin to the data center and the rotation of coordinate axes so that the abscissa passes in the direction of maximum dispersion of the data set (Fig. 2).

The results of main components analysis on the basis of correlation matrix are following:

Factor $1=0.375 \cdot \mathrm{Tm}+0.346 \cdot \mathrm{Kn}-0.469 \cdot \mathrm{Om}+$

$+0.181 \cdot \mathrm{Cr}-0.309 \cdot \mathrm{Hd}+0.282 \cdot \mathrm{Tr}+$

$+0.350 \cdot R c-0.073 \cdot N t-0.428 \cdot L c$,

$\lambda_{1}=2.13$
Factor $2=0.074 \cdot \mathrm{Tm}+0.155 \cdot \mathrm{Kn}+0.087 \cdot \mathrm{Om}-$

$-0.214 \cdot \mathrm{Cr}+0.497 \cdot \mathrm{Hd}+0.505 \cdot \mathrm{Tr}+$

$+0.298 \cdot R c+0.557 \cdot N t+0.126 \cdot L c$,

$\lambda_{2}=1.86$;

Factor $3=-0.467 \cdot \mathrm{Tm}+0.485 \cdot \mathrm{Kn}-0.053 \cdot \mathrm{Om}-$

$-0.639 \cdot \mathrm{Cr}-0.027 \cdot \mathrm{Hd}+0.034 \cdot \mathrm{Tr}-$

$-0.155 \cdot R c-0.169 \cdot N t-0.285 \cdot L c$,

$\lambda_{3}=1.82$,

where:

Factor $_{i}$ - component coordinates, complex environmental gradients;

$\mathrm{Tm}, \mathrm{Kn}, \mathrm{Om}, \mathrm{Cr}, \mathrm{Hd}, \mathrm{Tr}, \mathrm{Rc}, \mathrm{Nt}, \mathrm{Lc}$ - standardized values of herbaceous species ecological parameters (thermal regime, climate continentality, ombroclimate, cryoclimate, soil moisture, salt content, soil acidity, mineral nitrogen, luminosityshadowing regime);

$\lambda_{i}$ - eigenvalues of vectors.

From the characteristics analysis of eigenvalues $\lambda_{i}$, it follows that already the three main components provide about $70 \%$ of the total dispersion, therefore for many purposes of analysis it is enough to use a three-dimensional projection of the parent matrix data. The eigenvectors of the correlation 
matrix (1-3) make it possible to single out the ecological factors combinations that determine the axes of maximum herbaceous species diversity in the mining waste dumps of Chervonohrad coal mining industrial region. The main pattern of the ecotopes formation in the mining waste dumps (the first main component) has the following structure of relationships between the ecological parameters (Table 3): with a decrease in climate humidity parameters (correlation coefficient $r=-0.69)$, shadowing in cenosis $(r=-0.62)$ and soil moisture $(r=-0.45)$, the indexes increase of thermal regime $(r=0.55)$, continentality $(r=0.51)$, soil $\mathrm{pH}(r=0.51)$ and salt content $(r=0.41)$.

The first main component substantiates only $23.7 \%$ of the total dispersion, but based on its values, the main pattern of the ecotopes formation in the mining waste dumps is quite clearly observed. Thus, the low values of the first main component of Factor 1 are characte-ristic of the species that are indicators of fresh and moist, acidic and slightly acidic, nonsaline soils: Veronica officinalis, Dryopteris filix-mas, Solanum dulcamara, Oxalis acetosella, Scrophylaria nodosa, Poa nemoralis, Thymus serpyllum, Pulmonaria obscura, Chamaenerion angustifolium, Moehringia trinervia, Solidago virga-aurea. Mainly, these are species of nemoral-forest and boreal ecological-cenotic groups that are found in the reclaimed areas of the mining waste dumps with bulk soils under conditions of artificially created afforestation.

High values of the first main component are characteristic of species that are indicators of acidic-neutral, dry soils with features of low salinity characteristic of subarid (dry) territories: Reseda lutea, Coronilla varia, Alyssum alyssoides, Medicago lupulina, Medicago falcata, Setaria glauca, Tragopogon dubius. They occur in the ecotopes with vegetation of calcetrophilic, meadow-steppe, and upland meadow on the bulk substrate ecological-cenotic groups. The species ordination on the first maximum variation axis can serve as an indicator of anthropogenic impact. In the conditions of mining waste dumps in Chervonohrad coal mining industrial region, located in the forest zone, the ecological equivalent of increasing anthropogenic impacts is an increase in salt content, a decrease in soil acidity and moisture, an increase in temperature, and a decrease in the ombroclimate parameters. The patterns of geographical latitudinal zonality when changing from forest to steppe area can also be considered an ecological equivalent of this process.

The second axis of the maximum herbaceous species diversity in the mining waste dumps additionally substantiates $20.7 \%$ of the total data dispersion. The value of the Factor 2 function mainly depends on factors of soil moisture supply $(r=0,68)$, nitrogen content $(r=0.76)$ and salt content $(r=0.69)$. For example, Corynephorus canescens (Factor $2=-3.25$ ) is an indicator of dry, acidic, poor in salt and nitrogen sandy soils (J). Similar arrangement on the second axis of the maximum vegetation diversity is observed within the species of psammophilous and boreal ecological-cenotic groups: Thymus serpyllum, Scleranthus perennis, Trifolium arvense, Hieracium pilosella, Helichrysum arenarium. The maximum values of the second main component are characteristic of the hydrophilous ecological-cenotic group: Bidens tripartita, Alisma plantago-aquatica, Polygonum persicaria, Myosoton aquaticum, Typha angustifolia, Cucubalus baccifer, Epilobium roseum. The second axis of the maximum vegetation diversity to a certain extent reflects the patterns for vegetation cover formation in the mining waste dumps depending on the relief conditions. Thus, the species of hy- drophilous ecological-cenotic group are often found in excessively moistened areas of the dumps foot. Propagation of moisture-loving species is sometimes conditioned by the occurrence of small wetland complexes due to the dumps surface subsidence, as well as disordered mining of the rock.

The two main components provide only $44.4 \%$ of the total dispersion, therefore for many purposes of analysis it is not always sufficient to use only a two-dimensional projection of the parent matrix data (Fig. 2). Arrangement of the herbaceous species of the mining waste dumps on the third axis of maximum variation (Table 4) reflects an increase in continentality $(r=0.66)$ and a decrease in parameters of the thermal regime $(r=-0.63)$ and cryoregime $(r=-0.86)$. This axis is represented by ecological-phytocenotic series: nemoral-forest vegetation $\rightarrow$ psammophilous and downland meadow vegetation.

The vegetation cover in the mining waste dumps of Chervonohrad coal mining industrial region occupies a certain ecological-cenotic areal, which can be approximately assessed based on the species ordination on the axes of complex environmental gradients (Fig. 2).

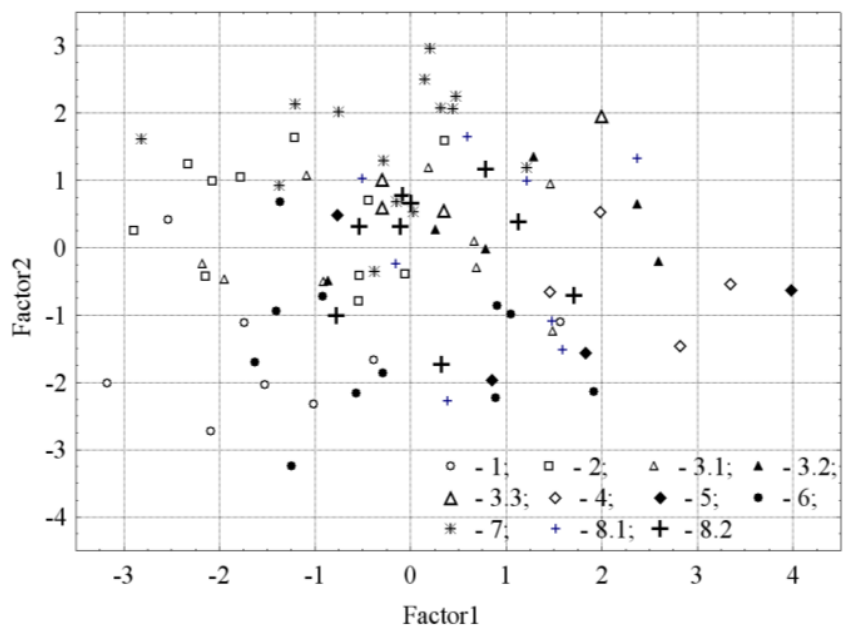

Figure 2. Ecological-cenotic areal of the vegetation cover in the mining waste dumps of Chervonohrad coal mining industrial region

The center of this areal is occupied by meadow and synanthropic species, which in the conditions of mining waste dumps demonstrate the greatest sustainability. These, in particular, are the species that form the highest projective cover at the initial succession stages: Calamagrostis epigeios, Chamaerion angustifolium, Poa pratensis, Oenothera biennis, Daucus carota, Achillea submillefolium. The most sensitive are the types of meadow-steppe, calciphilous, hydrophilous vegetation, the ecological-cenotic areal of which is characterized by the location on the periphery of the general vegetation space of the mining waste dumps. To some extent, nemoral-forest, boreal and psammophilous vegetation is also sensitive, the existence of which is connected with the application of an artificial soil substrate during the reclamation process.

Conventional signs of ecological-cenotic groups and subgroups of vegetation: 1 . Boreal; 2. Nemoral-forest; 3. Meadow; 3.1. upland meadow on the rock substrate; 3.2. upland meadow on the bulk substrate; 3.3. downland meadow on the bulk substrate; 4. Meadow-steppe; 5. Calcetrophilic; 6. Psammophilous; 7. Hydrophilous; 8. Synanthropic; 8.1. segetal; 8.2. ruderal 
Table 4. Coordination results of the ecological-cenotic groups and subgroups of vegetation cover in the mining waste dumps of Chervonohrad coal mining industrial region

\begin{tabular}{|c|c|c|c|}
\hline \multirow{2}{*}{$\begin{array}{c}\text { Ecological-cenotic group, subgroup } \\
\text { of vegetation }\end{array}$} & \multicolumn{3}{|c|}{$\begin{array}{l}\text { Arrangement on the axes of } \\
\text { maximum vegetation variation }\end{array}$} \\
\hline & Factor 1 & Factor 2 & Factor 3 \\
\hline Boreal & -1.36 & -1.57 & -0.52 \\
\hline Nemoral-forest & -1.20 & 0.49 & -1.35 \\
\hline Meadow & 0.32 & 0.36 & 0.72 \\
\hline $\begin{array}{l}\text { - upland meadow on the rock } \\
\text { substrate }\end{array}$ & -0.18 & 0.06 & 0.80 \\
\hline $\begin{array}{l}\text { - upland meadow on the bulk } \\
\text { substrate }\end{array}$ & 0.88 & 0.36 & 0.04 \\
\hline $\begin{array}{l}\text { - downland meadow on the bulk } \\
\text { substrate }\end{array}$ & 0.44 & 1.03 & 1.71 \\
\hline Meadow-steppe & 2.40 & -0.53 & -0.61 \\
\hline Calcetrophilic & 2.22 & -1.39 & -0.18 \\
\hline Psammophilous & -0.24 & -1.47 & 0.91 \\
\hline Hydrophilous & -0.29 & 1.56 & -0.16 \\
\hline Synanthropic & 0.56 & 0.00 & 0.07 \\
\hline - segetal & 0.88 & -0.02 & -0.53 \\
\hline - ruderal & 0.27 & 0.02 & 0.60 \\
\hline Mean & 0.00 & 0.00 & 0.00 \\
\hline Std. Dev. & 0.15 & 0.14 & 0.14 \\
\hline
\end{tabular}

Since the spaces of various ecological-cenotic groups of vegetation are being overlapped (Fig. 2), to determine the similarity of the ecotopes in the mining waste dumps, the coordinates of these spaces centers are used, as well as the average values of their ecological parameters (Table 2). Close location in the ecological-cenotic areal is demonstrated by:

1) boreal and psammophilous ecological-cenotic group;

2) upland meadow on the rock substrate and synanthropic ruderal ecological-cenotic group;

3) upland meadow on the bulk substrate and synanthropic segetal ecological-cenotic group;

4) meadow-steppe and calcetrophilic ecological-cenotic group.

Given the nemoral-forest, downland meadow on the bulk substrate and hydrophilous ecological-cenotic group, the peculiarities of the vegetation cover formation in the mining waste dumps of Chervonohrad coal mining industrial region are determined by seven types of conditions for growth places.

The typological scheme of the vegetation cover in the mining waste dumps can be represented in the form of a quadrangle, in the centre of which meadow and synanthropic vegetation is located, and in the corners: 1) boreal and psammophilous; 2) nemoral-forest; 3) hydrophilous; 4) meadow-steppe and calcetrophilic vegetation.

If to know the ecological parameters of flora species, it is possible to determine their arrangement in the ecologicalcenotic areal of the vegetation cover in the mining waste dumps of Chervonohrad coal mining industrial region, as well as to predict their dynamics. As an example, the main forest species, occurring in mining waste dumps, are characterized by the following arrangement in the typological scheme (Fig. 2): Pinus sylvestris L. (-1.83; 0.03; 2.10); Quercus robur L. (-1.08; 0.20; -1.04); Betula pendula Roth (-2.07; -0.22; 1.11); Populus tremula L. (-1.41; 0.68; 1.28); Salix caprea L. $(-2.71 ; 0.16 ; 0.36)$. High resistance to adverse waste dumps conditions is characteristic of forest species that have high values of the first main component Fac- tor 1 : Acer negundo L. (1.15; 0.56; -1.17), Salix purpurea L. (1.21; -0.06; -2.37), Robinia pseudoacacia L. (1.88; $1.10 ;-1.74)$, Amorpha fruticosa L. $(3.15 ;-0.03 ;-1.82)$, Hippophae rhamnoides L. $(3.24 ;-0.43 ; 0.53)$, Prunus divaricata Ledeb. (3.50; $1.04 ;-0.32)$.

The forest vegetation associations of the region occupy the following arrangement in the typological scheme: Molinio-Pinetum W. Mat. et J. Mat. 1973 - (-3.20; -0.87; 0.97), Peucedano-Pinetum W. Mat. (1962) $1973-(-2.70 ;-0.95$; 0.86), Querco-Pinetum J. Mat. $1982-(-3.63 ;-0.78 ; 1.29)$, Vaccinio uliginosi-Pinetum Kleist $1929-(-4.65$; -0.98 ; 2.95), pine wet moor Ledo-Sphagnetum magellanici Sucopp 1959 em. Neuhausl $1969-(-4.96 ;-1.25 ; 3.20)$.

\section{Conclusions}

A wide variety of conditions for vegetation growth places in the mining waste dumps of Chervonohrad coal mining industrial region, which is a constituent of the Lviv-Volyn coal basin, is determined by a complex combination of ecological factors. Anthropogenic impact is manifested by a decrease in the parameters of climate humidity and soil moisture, an increase in the indexes of thermal regime, continentality, soil $\mathrm{pH}$, salt content and luminosity in the cenosis. Improving the conditions of vegetation growth places and vegetation cover restoration can be achieved by terrace building on the slopes, as well as applying bulk soils to cover the mine rock.

The floristic core of the vegetation cover in the mining waste dumps of Chervonohrad coal mining industrial region is formed by meadow and synanthropic species with a wide range of tolerance, which can resist to adverse environmental conditions. The typological scheme of the vegetation cover in the mining waste dumps can be represented in the form of a quadrangle, in the centre of which meadow and synanthropic vegetation is located, and in the corners: 1) boreal and psammophilous; 2) nemoral-forest; 3) hydrophilous; 4) meadow-steppe and calcetrophilic vegetation.

\section{Acknowledgements}

The authors of this work express their gratitude to Professor V.P. Kucheriavyi for valuable consultations, as well as to two anonymous readers for useful recommendations, which greatly influenced this paper quality.

\section{References}

[1] Bashutska, U.B. (2006). Suktsesii roslynnosti porodnykh vidvaliv shakht Chervonohradskoho hirnychopromyslovoho raionu. Lviv, Ukraina: RVV NLTU Ukrainy.

[2] Kuziarin, O.T. (2012). Porivnialnyi analiz flory vuhilnykh vidvaliv Lvivsko-Volynskoho hirnychopromyslovoho rehionu. Biolohichni Studii, 6(2), 189-198.

[3] Popovych, V., Voloshchyshyn, A., Rudenko, D., \& Popovych, N. (2019). Geochemical properties of water under the waste heaps in Chervonohrad mining region. E3S Web of Conferences, (123), 01035. https://doi.org/10.1051/e3sconf/201912301035

[4] Malanchuk, Z., Moshynskyi, V., Malanchuk, V., Korniienko, Y., \& Koziar, M. (2020). Results of research into the content of rare earth materials in man-made phosphogypsum deposits. Key Engineering Materials, (844), 77-87.

[5] Abisheva, Z.S., Karshigina, Z.B., Bochevskaya, Y.G., Akcil, A., Sargelova, E.A., Kvyatkovskaya, M.N., \& Silachyov, I.Y. (2017). Recovery of rare earth metals as critical raw materials from phosphorus slag of long-term storage. Hydrometallurgy, (173), 271-282. https://doi.org/10.1016/j.hydromet.2017.08.022

[6] Abisheva, Z.S., Bochevskaya, E.G., Zagorodnyaya, A.N., Shabanova, T.A., \& Karshigina, Z.B. (2013). Technology of phosphorus slag processing for preparation of precipitated silica. Theoretical 
Foundations of Chemical Engineering, 47(4), 428-434. https://doi.org/10.1134/s0040579513040027

[7] Anfal Arshi. (2017). Reclamation of coalmine overburden dump through environmental friendly method. Saudi Journal of Biological Sciences, (24), 371-378. https://doi.org/10.1016/j.sjbs.2015.09.009

[8] Meshcheryakov, L.I., \& Shirin, A.L. (2011). Reclamation technology of land destroyed by mining and logistics monitoring criteria. Procedia Earth and Planetary Science, (3), 62-65. https://doi.org/10.1016/j.proeps.2015.08.077

[9] Kalybekov, T., Sandibekov, M., Rysbekov, K., \& Zhakypbek, Y. (2019). Substantiation of ways to reclaim the space of the previously mined-out quarries for the recreational purposes. E3S Web of Conferences, (123), 01004. https://doi.org/10.1051/e3sconf/201912301004

[10] Ling Zhang, JinmanWang, Zhongke Bai, Chunjuan Lv. (2015). Effects of vegetation on runoff and soil erosion on reclaimed land in an opencast coal-mine dump in a loess area. CATENA, (128), 44-53. https://doi.org/10.1016/i.catena.2015.01.016

[11] Song, Y., Shu, W., Wang, A., \& Liu, W. (2013). Characters of soil algae during primary succession on copper mine dumps. Journal of Soils and Sediments, 14(3), 577-583. https://doi.org/10.1007/s11368013-0815-y

[12] Popovych, V., Kuzmenko, O., Voloshchyshyn, A., \& Petlovanyi, M (2018). Influence of man-made edaphotopes of the spoil heap on biota. E3S Web of Conferences, (60), 00010 https://doi.org/10.1051/e3sconf/20186000010

[13] Kassymkanova, Kh., Jangulova, G., Bekseitova, R., Miletenko, N., Baidauletova, G., Turekhanova, V., Zhalgasbekov, Y., \& Shmarova, I. (2018) Express-assessment of geomechanic condition of the rock massive and development methods of its strengthening and reinforcing for safe ecological developing of the fields of mineral resources in hard mountain-geological and mining engineering conditions. News of the National Academy of Sciences of the Republic of Kazakhstan. Series of Geology and Technical Sciences, 6(432), 37-46. https://doi.org/10.32014/2018.2518-170X.33

[14] Baibatsha, A.B., Peng, S, \& Satibekova, S.B. (2019) Estimation of the physical-mechanical properties of the rocks on the degree of coal metamorphism. News of the National Academy of Sciences of the Republic of Kazakhstan. Series of Geology and Technical Sciences, 1(4330, 187194. https://doi.org/10.32014/2019.2518-170X.23

[15] Dryzhenko, A., Moldabayev, S., Shustov, A., Adamchuk, A., \& Sarybayev, N. (2017). Open pit mining technology of steeply dipping mineral occurences by steeply inclined sublayers. International Multidisciplinary Scientific GeoConference Surveying Geology and Mining Ecology Management, 17(13), 599-606. https://doi.org/10.5593/sgem2017/13/s03.076

[16] Levytskyi, V., Sobolevskyi, R., \& Korobiichuk, V. (2018). The optimization of technological mining parameters in a quarry for dimension stone blocks quality improvement based on photo-grammetric techniques of measurement. Rudarsko Geolosko Naftni Zbornik, 33(2), 83-89. https://doi.org/10.17794/rgn.2018.2.8

[17] Naduty, V., Malanchuk, Z., Malanchuk, E., \& Korniyenko, V. (2015) Modeling of vibro screening at fine classification of metallic basalt New Developments in Mining Engineering 2015, 441-443. https://doi.org/10.1201/b19901-77

[18] Malanchuk, Z., Korniyenko, V., Malanchuk, Y., \& Khrystyuk, A (2016). Results of experimental studies of amber extraction by hydromechanical method in Ukraine. Eastern-European Journal of Enterprise Technologies, 3(10(81)), 24-28. https://doi.org/10.15587/17294061.2016.72404

[19] Naduty, V., Malanchuk, Z., Malanchuk, Y., \& Korniyenko, V. (2016). Research results proving the dependence of the copper concentrate amount recovered from basalt raw material on the electric separator field intensity. Eastern-European Journal of Enterprise Technologies, 5(5(83)), 19-24. https://doi.org/10.15587/1729-4061.2016.79524

[20] Yermagambet, B.T., Nurgaliyev, N.U., Kazankapova, M.K., Kasenova, Zh.M., \& Abylgazina, L.D. (2019). Smokeless fuel production semi-coke from coal. News of the National Academy of Sciences of the Republic of Kazakhstan. Series of Geology and Technical Sciences, 2(434), 144-149. https://doi.org/10.32014/2019.2518-170X.48

[21] Reznik, A.M., Rozen, A.M., \& Abisheva, Z.S. (1976). Effect of organic-solvents on cesium extraction by para-alkylphenols. Zhurnal Neogranicheskoi Khimii, 21(4), 1140-1142.

[22] Petlovanyi, M., Lozynskyi, V., Zubko, S., Saik, P., \& Sai, K. (2019). The influence of geology and ore deposit occurrence conditions on dilution indicators of extracted reserves. Rudarsko Geolosko Naftni Zbornik, 34(1), 83-91. https://doi.org/10.17794/rgn.2019.1.8

[23] Matolych, B.M., Kovalchuk, I.P., \& Ivanov, Ye.A. (2009). Pryrodni resursy Lvivshchyny. Lviv: PP Lukashchuk.

[24] Diuk, V., \& Samoilenko, A. (2001). Data Mining. Saint Petersburg, Russian Federation: Piter.

[25] Kuziarin, O.T. (2011). Anotovanyi spysok cudynnykh roslyn vuhilnykh vidvaliv Lvivsko-Volynskoho hirnychopromyslovoho rehionu. Biolohichni Studii, 5(3), 155-170

[26] Tkachyk, V.P. (2000). Flora Prykarpattia. Lviv, Ukraina: NTSh.

[27] Degteva, S.V., \& Novakovskiy, A.B. (2011). Ekologo-tsenoticheskie gruppy sosudistykh rasteniy $v$ fitotsenozakh landshaftov basseyna verkhney i sredney Pechory. Ekaterinburg, Rossiya: UrO RAN.

[28] Tsyganov, D.N. (1983). Fitoindikatsiya ekologicheskikh faktorov v podzone khvoyno-shirokolistvennykh lesov. Moskva, Rossiya: Nauka.

[29] Didukh, Ya.P. (2011). The ecological scales for the species of Ukrainian flora and their use in synphytoindication. Kyiv, Ukraine: Phytosociocentre.

\section{Екологічні закономірності формування рослинного покриву гірничих відвалів шахт Львівсько-Волинського вугільного басейну}

\section{В. Скробала, В. Попович, В. Піндер}

Мета. Встановлення екологічних закономірностей формування рослинного покриву гірничих відвалів шахт ЛьвівськоВолинського вугільного басейну на основі аналізу флористичного складу екотопів рекультивованих і нерекультивованих териконів.

Методика. Використано фітоіндикацію екологічних режимів на основі екологічних параметрів трав'янистих видів рослинного покриву відвалів шахт; методи добування даних (Data Mining methods); багатовимірна ординація рослинних видів на основі аналізу головних компонент (Principle Component Analysis); статистична обробка екологічних параметрів екотопів породних відвалів шахт.

Результати. Виконано фітоіндикаційну оцінку умов місцевиростання 8 еколого-ценотичних груп та 5 підгруп видів рослин, які представляють різноманітні екотопи рекультивованих і нерекультивованих відвалів шахт, за дев'ятьма параметрами: $T m-$ термічний режим, $K n$ - континентальність клімату, $\mathrm{Om}$ - омброклімат, $C r$ - кріоклімат, $H d$ - вологість грунту, $T r-$ вміст солей, $R c-$ кислотність грунту, $N t$ - мінеральний азот, $L c$ - режим освітленості-затінення. Встановлено, що із зменшенням параметрів вологості клімату, затінення у ценозі і вологості грунту зростають показники термічного режиму, континентальності, рН грунту і вмісту солей. Рекомендовано типологічну схему рослинного покриву породних відвалів шахт представляти у вигляді чотирикутника, у центрі якого розташовані лучна і синантропна рослинність, а в кутах - бореальна і псаммофільна; неморальнолісова; гідрофільна; лучно-степова і кальцепетрофільна.

Наукова новизна. Виявлено, що рослинний покрив породних відвалів шахт Львівсько-Волинського вугільного басейну характеризується еколого-ценотичним простором, оцінку якого виконано на основі ординації видів на осях комплексних градієнтів середовища, при чому центр цього простору займають лучні і синантропні види, які в умовах породних відвалів шахт демонструють найбільшу стійкість. Найбільш вразливими є види лучно-степової, кальцефільної, гідрофільної рослинності, еколого-ценотичний простір яких характеризується розташуванням на периферії загального простору рослинності породних відвалів шахт.

Практична значимість. Встановлені екологічні параметри видів флори дозволяють визначити їх положення в екологоценотичному просторі рослинного покриву породних відвалів шахт Львівсько-Волинського вугільного басейну та прогнозувати їх стійкість і динаміку.

Ключові слова: гірнича справа, породний відвал, екологічна безпека, рослинність 


\section{Экологические закономерности формирования растительного покрова горных отвалов шахт Львовско-Волынского угольного бассейна}

\section{В. Скробала, В. Попович, В. Пиндер}

Цель. Установление экологических закономерностей формирования растительного покрова горных отвалов шахт ЛьвовскоВолынского угольного бассейна на основе анализа флористического состава экотопов рекультивированных и нерекультивированных терриконов.

Методика. Использована фитоиндикация экологических режимов на основе экологических параметров травянистых видов растительного покрова отвалов шахт, методы добычи данных (Data Mining methods), многомерная ординация растительных видов на основе анализа главных компонент (Principle Component Analysis), статистическая обработка экологических параметров экотопов породных отвалов шахт.

Результаты. Выполнена фитоиндикационная оценка условий местопроизрастания 8 эколого-ценотических групп и 5 подгрупп видов растений, представляющих различные экотопы рекультивированных и нерекультивированных отвалов шахт, по девяти параметрам: $T m$ - термический режим, $K n$ - континентальность климата, $O m$ - омброклимат, $C r$ - криоклимат, $H d-$ влажность почвы, $T r$ - содержание солей, $R c$ - кислотность почвы, $N t$ - минеральный азот, $L c$ - режим освещенности-затенения. Установлено, что с уменьшением параметров влажности климата, затенения в ценозе и влажности почвы растут показатели термического режима, континентальности, $\mathrm{pH}$ почвы и содержания солей. Рекомендовано типологическую схему растительного покрова породных отвалов шахт представлять в виде четырехугольника, в центре которого расположены луговая и синантропная растительность, а в углах бореальная и псаммофильная; неморальнолесная; гидрофильная; лугово-степная и кальцепетрофильная.

Научная новизна. Выявлено, что растительный покров породных отвалов шахт Львовско-Волынского угольного бассейна характеризуется эколого-ценотическим пространством, оценку которого выполнено на основе ординации видов на осях комплексных градиентов среды, причем центр этого пространства занимают луговые и синантропные виды, которые в условиях породных отвалов шахт демонстрируют наибольшую устойчивость. Наиболее уязвимыми являются виды лугово-степной, кальцефильной, гидрофильной растительности, эколого-ценотическое пространство которых характеризуется расположением на периферии общего пространства растительности породных отвалов шахт.

Практическая значимость. Установленные экологические параметры видов флоры позволяют определить их положение в эколого-ценотическом пространстве растительного покрова породных отвалов шахт Львовско-Волынского угольного бассейна и прогнозировать их устойчивость и динамику.

Ключевые слова: горное дело, породный отвал, экологическая безопасность, растительность

\section{Article info}

Received: 6 November 2019

Accepted: 10 May 2020

Available online: 15 May 2020 